\title{
Australian wages policy 1983-90
}

David H. Plowman*

This article reviews Australian wages policy in the period 1983 to 1990 . The period can be divided into 3 phases, each characterized by differing environmental and/or political circumstances impinging upon wages policy. The first phase, the period of the wages pause/freeze, ended with the National Wage Case of September 1983 when the Industrial Relations Commission reintroduced wage indexation. Full indexation was the hallmark of the second period, from September 1983 to March 1987. The deteriorating balance of payments situation led to the abandonment of indexation and the search for greater labour flexibility. The period since 1987 has been characterized by a wage regime which has attempted to impose a form of administered flexibility.

\section{The wages freeze and the return to indexation}

An earlier article in this journal described the political and economic circumstances leading to the Coalition Government imposing a 12-month wages freeze on the public sector and seeking to have the Industrial Relations Commission (hereafter the Commission) impose a similar freeze on the private sector (Plowman, 1984). The Commission imposed a 6 month "wages pause", a situation which was to be reviewed in June 1983.

By June 1983, the Coalition had been swept from office. Labor had used its period in opposition to build important links with the union movement by way of the Australian Labor Advisory Committee. One fruit of this committee was the Prices and Incomes Accord which attempted to tackle the twin problems of inflation and unemployment simultaneously. That policy differed from the "inflation first" policy of the Coalition. The Accord, agreed to by the union movement following the announcement of federal elections in February 1983, committed a future Labor government to the use of fiscal and monetary policy to stimulate employment. The union movement agreed to exercise wage restraint to ensure that government policies would not be merely inflationary. The Accord noted that:

... the fundamental feature of the prolonged and worsening economic crisis both here and overseas is that, for the first time in our history, we are experiencing simultaneously high levels of unemployment and inflation. This occurrence was not foreseen by economists and has caused great difficulty and uncertainty for governments in all countries in determining an appropriate economic policy (Australian Council of Trade Unions, 1983).

- School of Industrial Relations and Organizational Behaviour, University of New South Wales. 
After surveying attempts to curb stagflation by monetary policies, policies which had led to double digit unemployment and double digit inflation in Australia, the Accord partners noted:

It is with this experience in mind that both organisations have seen fit to try to develop a mutually agreed policy on prices and incomes in Australia for implementation by a Labor Government. Such a policy offers by far the best prospect of enabling Australia to experience prolonged higher rates of economic and employment growth, and accompanying growth in living standards, without incurring the circumscribing penalty of higher inflation, by providing for resolution of conflicting income claims at lower levels of inflating than would otherwise be the case. With inflation control being achieved in this way, budgetary and monetary policies may be responsibly set to promote economic and employment growth, thus enabling unemployment to be reduced and living standards to rise (Australian Council of Trade Unions, 1983).

The Accord has been an important plank underlying wages policy since March 1983 when Labor won office. Since that time there have been 6 variants of the Accord.

Shortly after winning the elections, Labor gave evidence of its "consensus" style of government by holding a National Economic Summit Conference. This conference, held in Parliament House Canberra, provided a forum for governments, employers, unions and other sections of the community to proffer approaches to national economic recovery. There was a general support for a centralized wage fixing system. The Summit Conference communique stated, inter alia:

19. All the parties believe that the principles of wage fixation should be such as to provide wage justice to all employees whilst seeking to ensure that wage increases do not give added impetus to inflation or unemployment.

20. It is believed that a centralised approach to wage fixation is the most equitable means by which the objectives can be met. It is recognised that if a centralised system is to work effectively as the only way in which wage increases are generated, a suppression of sectional claims is essential except in special or extraordinary circumstances proved before the centralised wage fixing authority.

21. The Summit therefore proposes that the parties should as a matter of priority develop the option of a return to a centralised system under the auspices of the Australian Conciliation and Arbitration Commission.

22. To progress the development of a centralised wage system a conference should be convened by the President of the Commission.

23. The centralised wage fixing principles developed by the Conciliation and Arbitration Commission should provided the framework for the operation of other wage-fixing tribunals in Australia, but the Summit recognises the authority and autonomy of these tribunals (National Economic Summit Communique, 1983).

In response to the communique, the Commission convened a wage fixing conference in late April 1983. This conference met irregularly until June and identified 23 issues which needed addressing. In the end result, the President noted that though there was agreement "regarding the need for a centralised system, there were differences as to the way in which the system should operate" (Moore, 1983). The Australian Council of Trade Unions (ACTU) sought the maintenance of real wages through wage indexation. The Confederation of Australian Industry (CAI) argued that real wages could only be maintained by increasing wages in line with productivity.

In August, the ACTU submitted national wage claims which compelled the Commission, not only to determine whether or not wage determination should be 
centralized, but also whether or not the "wages pause" should be extended. The government submission strongly supported a return to centralized wage determination:

... the consensus reached in the Accord and at the Summit would be undermined. It might not be possible for the Government to meet its commitment to bring about sustained economic recovery through an expansionary fiscal policy as the achievement of community restraint in terms of income claims depends on the successful implementation of the prices and income policy. Even short term stimulus could be ruled out.

The task of reducing unemployment would be made more difficult and dependent almost entirely on external factors and on the extent of recovery of the world economy in particular. Some may suggest that the current economic crisis and in particular the high rate of unemployment and fear of job security would temper demands for wage increases. While this is an arguable position, the government's view is that it probably would not be so (Australian Conciliation and Arbitration Commission 1983, p.13).

Not only did the Labor Government support the return of a centralized system which its predecessor had opposed, it further sought the return of wage indexation, a system largely scrapped at the request of the previous Government:

Fundamental in the Government's approach to the centralised system is the high degree of real wage security it must offer to wage and salary earners. Only in exceptional and compelling circumstances should any departure from full indexation occur. In our submission, without this degree of certainty the system could not provide the stability in wage determination for the medium and longer term that is crucial in the government's prices and incomes policy (Australian Conciliation and Arbitration Commission, 1983, p.15).

Based on the 1975 to 1981 experience, the Commission noted that a full indexation system, to be sustainable economically and industrially, had to meet a number of requirements. The Commission drew attention to 8 requirements. Wage increases outside National Wage cases had to be minimal. Thus, the system had to contain "an acceptable and workable procedure for dealing with non-conformists". The "nature and requirements of the centralised system [had to be] understood at ail levels of the trade unions movement". The Accord parties had a responsibility for ensuring this requirement was met. There was also the need to accept "that it may be necessary to grant less than full indexation on rare occasions". Restraint on prices and non-wage incomes was considered an important factor in sustaining wage restraint. The Commission noted that the Accord provided for the development of mechanisms such as a Prices Surveillance Authority and "taxation measures to ensure that non-wage incomes in general do not move out of line with movements in wages and salaries". There was also the need for the Government to take account of taxation effects, both direct and indirect, on wage claims. There was the need for the ACTU to abandon claims for wage losses during the period of the freeze or "pause". Finally, the principles had to be applied consistently and rigorously by all members of the Commission.

The Commission formulated national wage guide-lines to these ends. In summary, these provided for: (a) Half yearly indexation in relation to the Eight Capital Cities Consumer Price Index (CPI) "unless it was persuaded to the contrary by those seeking to oppose the adjustment". The form of indexation was to be "uniform percentage adjustment unless the Commission decides otherwise in the light of exceptional circumstances". (b) Upon application the Commission would consider whether there should be any improvements in wages or working conditions on account of national productivity. No applications on this ground would be considered before 1985 . (c) Unions seeking national wage increases had to give an undertaking to comply with the principles. (d) Limiting and strenuous provisions were provided for wage increases on 
account of changes in work value - changes in the nature of the work, skill and responsibility required, or the conditions under which the work is performed. (e) Procedures were established for dealing with wage anomalies and inequities. These were to be processed through peak union and employer bodies by a Full Bench of the Commission.

The principles became operational on October 6, at which time those unions prepared to give the required undertakings had their award wages increased by 4.3 percent. Only 2 unions prevaricated before giving the required undertakings.

In April 1984, the Commission convened a National Wage case to consider claims relating to the movements in the CPI for the September and December 1983 quarters of 1.6 percent and 2.4 percent respectively. The Commission heard evidence of "tentative" signs of economic recovery. There had been a fall in the rate of unemployment from 10.3 percent in June 1983 to 9.4 percent in February 1984. Job vacancies had risen. Both farm and non-farm Gross Domestic Product grew strongly in the September quarter. The OECD had forecast a growth in Australia's GDP of 5.25 percent for 1984. There had been an upturn in manufacturing and dwelling construction. The balance of payments on current account had benefited from the improvement in exports and a decline in imports. There was evidence of a recovery in the world economy.

Though there was broad agreement on the state of the economy, there were sharp differences about the proper course for wages. Employers and the Tasmanian and Northern Territory governments opposed any wage increases. If the Commission was of a mind to grant wage increases, the CAI requested discounting of the CPI for government charges and tax induced price increases. The Queensland Government sought plateau indexation with the threshold being the Average Minimum Weekly Award rate. In support of their claim for a full 4.1 percent increase, the ACTU and the Commonwealth placed considerable emphasis on the Accord as the basis for economic recovery. The ACTU argued:

... the policies of the Accord provide the basis for continued government stimulus necessary to further develop the initial economic improvement, provide a stable wage fixation environment and through the Medicare effect provide the means for a specific and significant anti-inflationary effect (Australian Conciliation and Arbitration Commission, 1984, p.9).

In supporting the application for the full 4.1 percent the Commonwealth submitted:

If the centralised system were to falter at an early stage of its development then the consequences for both industrial relations and economy recovery would be serious indeed. It is essential that the centralised system retains the confidence of wage and salary earners by safeguarding their living standards. That will contribute to the effectiveness of the prices and incomes policy and will ensure that wage outcomes remain consistent with economy recovery (Australian Conciliation and Arbitration Commission, 1984, p.9).

The prices and incomes Accord, the Government noted, was the "cornerstone of its economic strategy".

After surveying government-induced price increases the Commission rejected the CAI's submission for CPI discounting. In the light of post-1986 decisions, its reasoning is worth noting:

The adoption of CAI's reasoning on this question could well lead to partial indexation on a regular basis, an approach which would be inconsistent with the concept underlying the present indexation package. Further, we believe that to interfere with the CPI by way of discounting, even if justified on economic logic, may reduce confidence in the present system and weaken 
commitment to it (Australian Conciliation and Arbitration Commission, 1984, p.12).

The Commission granted the unions' claim for a full 4.1 percent increase.

The wage guide-lines adopted in September 1983 should have resulted in a second National Wage case commencing in August 1984 to review CPI increases for the March and June 1984 quarters. However, both these quarters were affected by the Bureau of Statistics' treatment of the method of financing medical services under the Medicare scheme. This resulted in a reduction in the CPI for those quarters of 2.5 percent. The overall movement in the CPI for the first 2 quarters of 1984 was -0.4 percent and 0.2 percent respectively, a net outcome of -0.2 percent. At a conference chaired by the Commission's President, it was agreed that there would be no union or employer applications for the March and June quarters. The agreement stated:

1. All parties indicate that they do not propose to make an application for the scheduled hearing in respect of the -0.2 percent CPI figure.

2. The ACTU will make an application to the next National Wage Case in February to consider movements in the CPI in the September and December quarters 1984.

3. All parties will have the right to argue as to the way in which the -0.2 percent should be treated in the context of that hearing. The ACTU has indicated that it will oppose any discounting of its application by the -0.2 percent.

4. All parties have the right to make such submissions about the Principles as they think fit.

5. Further discussion will take place between the CAI and the ACTU regarding certain outstanding alleged anomalies (Moore, 1984).

The National Wage cases of 1985 were accompanied by optimistic economic outlooks. In the case which concluded in April, the evidence suggested that employment had risen by 3.3 percent over the previous 12 months while the rate of unemployment had fallen from 9.4 to 8.3 percent. Wages drift (i.e. wage increases outside indexation) was minimal. There was a significant fall in average real unit labour costs. The profit share of GDP was back to historic norms. Retail sales were up, as was private investment. International economic recovery was expected to continue throughout 1985 . There were, however, areas of concern: the rate of unemployment was still very high; there had been a sharp depreciation of the Australian dollar which threatened to rekindle inflation; interest rates were again on the increase; there was a marked deterioration in the balance of payments deficit of about $\$ 9.5$ billion. Over time, these areas of concern forced a change in wages policy.

The ACTU, supported by the Commonwealth, sought full indexation. The Commission acceded to the claim and granted award wage increases of 2.6 percent (Australian Conciliation and Arbitration Commission, 1985a).

At the November National Wage case, 3 matters were under consideration: union applications for wage increases of 3.8 percent to reflect increases in the CPI; union applications for 4 percent increases in wages or improvements in conditions of employment on account of national productivity; and a CAI application for a review of the Principles of wage determination.

Though the economy had continued to grow and unemployment to fall, the accumulating overseas indebtedness was a major source of concern. The floating of the Australian dollar had resulted in its depreciation by 20 percent (trade weighted). "The size of the devaluation", the Commission noted, "is tangible warning that Australia has been borrowing too heavily from abroad as reflected in the size of the balance of payments and the international debt". (Australian Conciliation and Arbitration Commission 1985b, p.10). There was also a realization that devaluation could benefit the manufacturing 
sector, but only if the imported component of the CPI was not reflected in wage adjustments. Of the 3.8 percent CPI increase, the Australian Bureau of Statistics estimated that 1.2 percent was the result of overseas factors. Employers submitted that the CPI should be discounted for the effects of devaluation.

Because of the Labor Government's strong submission to the effect that Commission should take into account the effects of devaluation, the ACTU had a real concern that discounting would take place. This would have put it in a difficult position in being able to guarantee the "substantial compliance" requirements under the wage guidelines. Another critical consideration was that the National Wage case opened at about the same time as the ACTU was holding its biennial congress. It had to act to remove the potential friction between it and its affiliates as well as between itself and the Government. As it happened, changes in the Liberal Party also played a part in developments. In the week of the congress, Mr J. Howard, a "dry" committed to labour market deregulation, became Leader of the Opposition. This added to the imperative for the political and industrial wings of the labour movement to reach some workable arrangement. This was enshrined in the Accord Mark II which was endorsed by the congress. In summary, this provided for: (a) A full national wage adjustment of 3.8 per cent in the current case and a deferment of any discounting for devaluation to the next national wage case which was expected to be held in April 1986. The discounting on that occasion would cover the direct effects of the devaluation on the CPI for the four quarters of 1985 but would be limited to 2 per cent. To compensate for the discounting, the Government agreed to reduce income tax rates from September 1986. (b) The 4 per cent productivity claim would be pursued by way of an improvement in occupational superannuation. Negotiations on superannuation could proceed on the understanding that the cost impact of any new or improved arrangements would not occur before July 1986. (c) The existing principles would continue in force until replaced by the Commission.

This agreement gave the Government a major victory - the first time in history that the ACTU had agreed to discounting. There were 2 other advantages of the agreement. The Government was able to counter opposition claims to the effect that it had been impotent in getting union agreement on treating devaluation as a special case, thus reducing the longer-term potential of devaluation. The Government was also able to ensure that the 4 percent productivity claimed by the ACTU was not to be paid in the form of wages. Rather, it had been linked to the Government's own agenda of trying to reduce the long-term problem of an ageing population dependent upon welfare payments.

The Accord Mark II resulted in the Commission delaying consideration of the discounting of the CPI to the first National Wage case of 1986. It also enabled the Commission to postpone consideration of the productivity claim. Thus, the only major consideration was the claim for a 3.8 percent CPI adjustment.

Having lost out on the devaluation route, employers had a difficult case to argue. They claimed that the economy could not afford wage increases - a claim made at every National Wage case. They further claimed that industrial disputes were a factor which ought be taken into account and which should lead to discounting. They were not helped in this argument by the fact that the industrial disputation was at its lowest level in 20 years, nor by the fact that the guidelines provided that specific industries experiencing disputation could apply for exemptions to wage increases. The Commission awarded the full 3.8 percent

In February 1986, the Commission began hearing the National Productivity, Review of Principles and National Wage case. Judgement was not delivered until June. The case involved 3 substantive issues: the review of the Wage Fixing Principles; union application for wage adjustments of 2.5 percent based upon CPI movements in the September and December 1985 quarters; and union applications for a "4\% increase in wages and salaries or improvements in conditions by way of superannuation based on national productivity and amounting to a $3 \%$ wage equivalent" (Australian Conciliation and Arbitration Commission, 1986a, p.2). 
The Bench heard arguments from some employer quarters for the abandonment of the centralized system in favour of industry by industry or establishment by establishment wage determination. In determining to maintain a centralized system the Commission claimed to "have taken into account the merits of the submissions in theory and in practice". It had come to the conclusion that "in the present circumstances, the continuance of a structured centralised system provides the best prospects for maximum labour cost restraint together with reasonable industrial stability, both essential ingredients for economic recovery". It added:

We base this conclusion partly on the absence of any convincing material which would indicate how any alternative system would operate, and partly and more positively on our understanding of labour market institutions in this country. ... The decentralised, award-by-award system proposed ... ignores important practical considerations. First, the institutional framework within which industrial relations is conducted which includes a multiplicity of awards within each industry, many of them extending to a number of industries; the operations of Federal and State tribunals in particular industries; the occupational structure of unions; and a multiplicity of employer groups. These institutional characteristics which operate in Australian labour markets are a far cry from the simple enterprise-oriented industrial relations systems on which the submissions from decentralised wage fixing appear to be premised. Second, the decentralised approach gives little weight to the high probability that firms or industries, each acting independently in accordance with its own perceived interest, in conjunction with trade unions doing likewise, can result in a general wage increase greatly in excess of the capacity of the economy. The pressure of comparative wage justice is a real force in industrial relations. The strength of this concept, the place it holds in the thinking of employers and employees, even with high unemployment, together with the institutional characteristics of the labour market, to which we have referred, would ensure that across-theboard wage increases of similar amount would occur, and not varying increases based on capacity of individual industries an establishments. Thus, for example, a local or sectional settlement agreed to in a strategic industry, based on its ability to absorb or pass on wage increases, would flow generally regardless of the economic capacity of individual firms or industries. The perceived advantages of a decentralised system so eloquently argued by its proponents on the basis of the experience of select countries is illusory and at best transient in the context of the current Australian labour market. This is so clearly exposed in the experiences of the late 1960 s and more recently during $1981 / 82$, that it is surprising that the proponents of decentralisation should continue to ignore the lessons of history and their underlying institutional bases (Australian Conciliation and Arbitration Commission, 1986a, p.4).

The Commission decided to extend to July 1988 the Wage Fixing Principles, subject to some modifications. The most important of these was the inclusion of a new Principle 3 dealing with superannuation. This provided for the certification of consent agreements regarding employer contributions to approved superannuation funds from a date to be approved by the Commission and not before 1 January 1987 . Such contributions were not to involve the equivalent of a wage increase in excess of 3 percent of ordinary time earnings, and could not involve retrospective payment of contributions. The requirement for a consent award limited the extension of superannuation to those cases where employers and unions could reach agreement. This new Principle, the Commission hoped, would take account of the ACTU's productivity claim.

In considering the wage claim, the Commission again canvassed the state of the economy. Since the introduction of the Wage Fixing Principles in September 1985, fulltime employment had grown by 8 percent while total employment had grown by 10 percent. Unemployment had fallen from 10.3 percent to 7.9 percent despite a substantial increase in the labour force participation rate. On the basis of a constant participation 
rate, the unemployment rate would have fallen to 5.2 percent. The number of working days lost through strikes had fallen to 40 percent of the average annual level of the preceding 10 years. Further, until the devaluation effect on prices came into play, the inflation rate had fallen substantially - from 11.5 percent in $1982-83$ to 5.8 percent in 1984-85. Following virtually no growth in 1982-83, non-farm GDP grew by 3.5 percent, 4.6 percent and 4.0 percent in $1983-84,1984-85$ and $1985-86$ respectively. The Bench concluded:

Before dealing with the current economic difficulties it is important to acknowledge the record of economic achievement since September $1983 \ldots$ as well as the role played by the Wage Fixing Principles. It would be noted that the danger and difficulties of a wage explosion, so often encountered after a prolonged wage pause, were avoided in the transition to a policy of labour cost restraint under a structure centralised system (Australian Conciliation and Arbitration Commission, 1986a, p.4).

The Achilles heel of economic management, however, continued to be the external sector. Devaluation had reversed the downward spiral in prices. The CPI increase for the year ending March quarter 1986 was 9.1 percent. The price of Australian commodities, in particular wool, wheat, minerals and metals had fallen, resulting in a further deterioration of the terms of trade. Thus, while the volume of exports and imports rose by 14.1 and 0.9 percent respectively over the 12 months to the March quarter 1986, their corresponding values rose by 18.9 and 21.5 percent. The Commission concluded:

In summary, since we embarked on the centralised system in September 1983, the economy had made rapid gains in terms of growth in GDP and employment; the unemployment rate although still unacceptably high has fallen; wage increases have come down markedly; real unit labour costs are down at or close to the levels of the late 1960s; and profit shares are back at or close to the rates of the late 1960s. All this has happened in a much more stable industrial relations climate in which Wage Fixing Principles have generally been adhered to in an orderly way with little earning drift due to over award payments and some 96 percent of total earnings being attributed to national wage.

However, the recovery has encountered a persistent and serious balance of payments problem which, in floating exchange rate regime, has led to a substantial devaluation of the Australian dollar. This problem is in part due to the very rapid growth of the Australian economy itself in the context of much slower growth in the world economy; but it has been more seriously affected by a very adverse movement in Australians terms of trade. While it is not unusual for the terms of trade to worsen following a devaluation, the extent of devaluation is largely due to the considerable fall in world commodity prices which affects the bulk of our exports. The signs are that these prices will remain low in the next 2 years. Unless the deficit in the balance of payments is reduced, the growth in our external debt is halted and the Australian dollar is stabilised, the economy faces the prospect of losing all the gains made in the last 3 years (Australian Conciliation and Arbitration Commission, 1986a, p.4).

The unions' claim was based on the 4.3 percent increase in the CPI for the September and December 1985 quarters. In accordance with the Accord Mark II, the ACTU agreed to discounting of up to 2 percent. The Commission discounted by this amount and awarded wage increases of 2.3 percent. It further determined that the next National Wage adjustment would not operate before January 1987. Thus the 2.3 percent increase would be the only National Wage increase in 1986.

The Commission remained confident that the centralized Wage Fixing Principles which it had adopted in September 1983, and whose operation it had decided to extend to July 1988, would provide the appropriate wage environment for redressing the economic problems. Indeed, in its June 1986 judgement, the Commission opined that "fiscal and 
monetary measures have been applied to slow down the growth of domestic demand; and although it is too soon to be confident, there are signs that the balance of payments is beginning to turn around" (Australian Conciliation and Arbitration Commission, 1986a, p.13). This optimism proved unfounded.

In November 1986, the Commission again met to consider National Wage adjustments. It considered union applications seeking 6.7 percent increases "to compensate for the movement in the CPI for the 9 months ended September 1986" (Australian Conciliation and Arbitration Commission, 1986b, p.4). There were a number of employer applications "to provide a vehicle for a test case on the removal of the annual leave loading from Federal awards". The CAI sought a review of the Principles of Wage Fixing adopted in June 1986 and further sought "to have superannuation fully considered in the context of the Review" (Australian Conciliation and Arbitration Commission, 1986b). Again, attention focused on the balance of payments problem. The Commonwealth submitted:

Corrections of the imbalances that have developed in Australia's external accounts is necessary. If this is not done, the economy runs the risk of becoming enmeshed in a vicious circle of exchange rate depreciation, mounting inflation and deepening external imbalances.

This would result in an erosion in overseas and domestic confidence in the economy's future, seriously undermining private investment, economic activity and employment. The current account deficit would eventually be reduced but at a cost of a deep recession in the economy (Australian Conciliation and Arbitration Commission, 1986b).

The ACTU realized that the economic situation, in particular the serious deterioration in the balance of payments, would possibly produce only partial indexation. This could seriously weaken, if not destroy, support for the current system of wage fixation. With that in mind, the ACTU submitted "that in advance of the current system self-destructing, we have sought as a fall-back or secondary position a modified approach" (Australian Conciliation and Arbitration Commission, 1986b, p.5).

The ACTU's modified approach envisaged a 2-tiered system. The first tier would be generalized wage increases for all wage earners by way of a National Wage determination. The second tier would provide for wage adjustments, to a predetermined ceiling, for improved efficiency. This 2-tiered approach found support from the Commonwealth and the CAI. The case was adjourned to a conference to be convened by the President in January 1987. The principle purpose of the conference was the determination of new wage guidelines.

\section{The 2-tiered system}

In March 1987 the Commission announced the 2-tiered wage guidelines. The first tier provided for a National Wage increase of $\$ 10$ per week and provision for the Commission to consider a further 1.5 percent increase in October 1987. The second tier provided for a further 4 percent increase on account of improved efficiency. To this end, the Commission introduced the Restructuring and Efficiency Principle. This stated:

(a) Increases in rates of pay or improvements in conditions of employment may be justified as a result of measures implemented to improve efficiency in both the public and private sectors.

(i) Changes to work practices and changes to management practices must be accepted as an integral part of an exercise conducted in accordance with this principle. 
(ii) Other initiatives may include action to reduce demarcation barriers, advance multi-skilling ${ }^{1}$ training and re-training, and broad-banding. ${ }^{2}$

(iii) Changes in work practices may be necessary.

(b) This principle shall be subject to the second tier ceiling [of 4 percent]

(Australian Conciliation and Arbitration Commission, 1987, p.36).

The Commission identified some of the positive changes it expected to flow from the new principle:

- There will be an examination of restrictive work and management practices in both the private and public sectors to identify areas of inefficiency and to develop means to overcome them;

- if improved efficiency and productivity require the introduction or extension of multi-skilling and broad-banding, these will be traded by the parties as an appropriate element in the restructuring exercise.

- similarly, there should be acceptance of the concept that the reduction of demarcation barriers may be essential to the success of an exercise; and where new classifications are needed to give effect to the change which have been introduced, the parties will seek an appropriate award variation (Australian Conciliation and Arbitration Commission, 1987, p.13).

This decision marked a major change in traditional National Wage determination. Historically such wage determination adjudicated upon income distribution. This National Wage decision called for cost offsets. Thus it was as concerned with income generation as income distribution. Further, the decision attempted to decentralize the second tier. Though it considered that nationally agreed guidelines could assist in the proper processing of enterprise-based restructuring and efficiency exercises, it stressed that "it [was] primarily at the enterprise level that the objective of this principle [would] be achieved".

Surveys by the Department of Industrial Relations indicate that over 80 percent of employees covered by awards had received second tier wage increases by January 1989 . This figure increased to nearly 100 percent by the end of that year (Deparment of Industrial Relations, 1990).

The Department surveys identified 5 major areas in which changes had occurred. The most common of these was changes in the method of payments, in particular the move to the electronic transfer of wages. In a number of other cases, provision was made for payment by cheque.

The second area identified was the more flexible use of labour. A considerable number of second-tier agreements provided scope for multi-skilling, broad-banding and the development of career paths. In some cases there was provision for the greater use of part time and casual labour. There was also provision for the handling of demarcation disputes and the removal of demarcation barriers.

The third area identified was the provision of grievance procedures for avoiding or settling industrial disputes.

The fourth area concerned the greater spread of working hours and the reduction in non-productive time (e.g. wash-up time, tea breaks etc). Other agreements provided for improved shift arrangements, greater flexibility in rostered days off and during public holidays and shut-down periods.

The fifth area concerned management practices and quality control. Many second-tier agreements made provision for the introduction of Total Quality Control programs.

1 The term "multi-skilling" refers to the provision of further training to current employees to enable them to carry out tasks not covered by their present job classification.

2 The term "broad-banding" means the bringing together under a single classification or title a number of jobs that were separately or individually classified. It is a reduction in the total number of differently classified jobs within an award or enterprise. 
Others provided for improved communication, consultation and information sharing arrangements.

Despite these positive outcomes, there were reservations regarding the continuance of the 2-tiered system. There was concern regarding the limitations on "trade-off" exercises, in particular in the most efficient enterprises.

These concerns were reviewed at the June-July National Wage case of 1988 . The ACTU submitted that the Restructuring and Efficiency Principle had helped eliminate inefficient practices and to increased flexibility. It supported the continued operation of a principle aimed at restructuring, but felt that such a principle needed a broader and longerterm scope so as to facilitate award restructuring, skill acquisition and changes to work organization. The Commission concluded that the March 1987 Principles had been "reasonably successful":

The proper application of the restructuring and efficiency principle called for a position approach by trade unions, their members and individual workers and by employer organizations, their members and individual employers. In the Commission's experience some were inadequate for the task. Many others made positive efforts: the best not only derived benefits which produced immediate efficiency and productivity improvements but also laid the foundations for future improvement (Australian Industrial Relations Commission, 1988, p.5).

The Commission maintained a 2-tiered approach to wages but replaced the Restructuring and Efficiency Principle with the Structural and Efficiency Principle. This Principle was designed to:

provide incentive and scope within the wage fixation system for parties to examine their awards with a view to:

- establishing skill-related career paths which provide an incentive for workers to continue to participate in skill formation;

- eliminating impediments to multi-skilling and broadening the range of tasks which a worker may be required to perform;

- creating appropriate relativities between different categories of workers within the award and at enterprise level;

- ensuring that working patterns are arrangements enhance flexibility and meet the competitive requirements of the industry ... (Australian Conciliation and Arbitration Commission, 1988, p.6).

The Commission noted that the new principle was designed to facilitate fundamental reviews of awards to ensure that their structures remained relevant to the requirements of modern competitive industry. It was not intended to "be applied in a negative costcutting manner or to formalise illusory, short-term benefits". The new Principle stated:

Structural Efficiency;

Increases in wages and salaries or improvement in conditions ... shall be justified if the union(s) party to an award formally agree(s) to co-operate positively in a fundamental review of the awards with a view to implementing measures to improve the efficiency of industry and provide workers with access to more varied, fulfilling and better paid jobs. The measures to be considered should include but not be limited to:

- establishing skill-related career paths which provide an incentive for workers to continue to participate in skill formation;

- eliminating impediments to multi-skilling and broadening the range of tasks which a worker may be required to perform; 
- creating appropriate relativities between different categories of workers within the award and at enterprise level;

- ensuring that working patterns and arrangements enhance flexibility and the efficiency of the industry;

- including properly fixed minimum rates for classification in awards, related appropriately to one another, with any amounts in excess of these properly fixed minimum rates being expressed as supplementary payments;

- updating and/or rationalising the list of respondents to awards;

- addressing any cases where award provisions discriminate against sections of the work-force (Australian Conciliation and Arbitration Commission, 1988).

In February 1989, the National Wage Bench met to review the Structural and Efficiency Principle. It handed down its decision in May. "Most of the parties and intervenors", the Bench noted, "informed the Commission of the progress that has been made in the areas they represent." The Bench added:

The material indicated that progress is uneven and varies from industry to industry and enterprise to enterprise. It also showed that negotiations are proceeding at different levels and that, in some cases, progress is slow because of disagreement over the agenda and procedure. Preparedness to consider change also appears to vary widely. Progress in some areas is considerable but in the majority is minimal. Notwithstanding that, we are satisfied that the principle as framed in the August 1988 decision can and should facilitate negotiations over a wide range of issues and award areas (Australian Industrial Relations Commission, 1989a, p.2).

The Commission accepted, in principle, the ACTU's submission for a national framework or "blueprint" approach to restructuring. That blueprint would provide "consistent, coherent award structures" based on training and skills acquired, and which "would bear clear and appropriate work value relationships one to another". The ACTU sought endorsement of proposed wage relativities spanning the building, metal, warehousing, road transport and clerical industries. It has been argued elsewhere that this blueprint approach could have the effect of replacing one rigid wages system with another equally rigid and inflexible system (Plowman, 1990).

In June 1989 the National Wage Bench convened yet again:

to determine whether any wage adjustment should be made having regard to the progress of award restructuring, the tax changes that have been announced, the state of the economy and the extent to which unions are prepared to make the necessary commitments" (Australian Industrial Relations Commission, 1989b).

It decided to adjust wage rates between $\$ 10$ and $\$ 15$ per week with a second increment to be added 6 months later. The commencement date of the first increase was to be the date "on which an award is varied following examination by the Commission of the proposals for restructuring and the giving of commitments". This decision was intended as a spur to restructuring negotiations. Furthermore, "the second instalment of the structural efficiency adjustment should only be available if the Commission is satisfied that the principle has been properly implemented and will continue to be implemented effectively" (Australian Industrial Relations Commission, 1989b).

Such negotiations have continued but have not been the subject of empirical analysis to date. A National Wage review, scheduled for May 1990, has still to hand down its decision. It is to the Accord Mark VI that one may turn to seek an indication of the future of wage determination. 


\section{The Accord Mark VI}

The Accord, first agreed to in 1983, has been the instrument of joint ACTUGovernment approaches to the Commission. In essence, the union movement has bartered with the Government over an improved social wage regime and reduced taxation in return for wage moderation. The Accord has been singularly successful in averting a wages explosion following the lifting of the wage freeze. Similarly, the Accord was the vehicle whereby wage indexation was abandoned without the political and industrial dislocation which accompanied the demise of indexation in 1981. Remarkably, the Accord has been the instrument of real wage reduction (in the order of 10 to 11 percent) without major strikes. Under the Accord, the ACTU has agreed to CPI discounting. The Accord has also provided a facilitative environment for award restructuring and for changing the National Wage focus on income distribution to include income generation.

The latest version of the Accord was agreed to in February 1990. This states that the common objectives of the Labor Government and the ACTU for industrial relations in the 1990s are to: improve industrial relations, increase employment, lower inflation and interest rates, improve living standards, improve the productivity and the quality of employment, increase savings for retirement, and rationalize union and award coverage. The essence of the Accord strategy is reaffirmed:

During 1990-91, the parties will, by a combination of wage increases, tax reductions and improvements in the social wage, provide for an increase in disposable incomes and living conditions while achieving a sustainable reduction in inflation and interest rates (Australian Council of Trade Unions, 1990).

There is a recognition by both parties "that the immediate priority in industrial relations is to continue with the award restructuring process. To this end, unions have given a number of commitments to facilitate restructuring." There is also acceptance that the restructuring exercise

must be accompanied by reasonable wage increases which are consistent with aggregate economic outcomes ... to this end the parties agree to work within an aggregate wage target of 7 percent for the year 1990/91 (Australian Council of Trade Unions, 1990).

It was proposed that both the ACTU and Government make submissions to the next National Wage review seeking 2 wage increases for 1990: a first increase "to maintain the real value of wages in the September quarter $1990 \ldots$ and a further increase of $\$ 12$ per week 6 months later". The second instalment was predicated on an inflation rate of 6 percent, a potentially conservative figure in the light of increased petroleum prices. The Accord provides that in the "event that the annualised rate of inflation is expected to exceed that figure, the parties will review the second adjustment with the objective of at least maintaining real disposable income and to meet the agreed aggregate wage target". The Accord further provides for a second superannuation instalment of 3 percent. There is also provision for over award payments by the variation of the "no extra claims commitments ... to provide the opportunity for claims based on achieved increases in productivity and profitability with restructuring". The Government has promised tax cuts of about $\$ 7.50$ for those on average weekly earnings and improvements in the social wage.

At the time of writing, wages policy is at an impasse. As already noted, the proposed May review of wages policy has been delayed, in large measure because of the illness of the President. Thus the 2 wage increases agreed to in the Accord are in abeyance. The Accord's potential underestimating of rate of inflation, its seeming assent to a return to full indexation, its watering down of the no further claims provisions and 
its added superannuation imposts have made it less attractive to employers or the Commission.

In the event of a Wages Principles review the Accord partners may find, for the first time, that they lack Commission endorsement for their agreement. The ACTU has sought to forestall this situation by winning assent from large employers through direct action. If successful, the National Wage review would be presented with a fait accompli with respect to these employers and could have difficulty not flowing on the results to other sectors of the work force. To date, employers have largely resisted union pressures and have threatened to make applications themselves for a National Wage review. The Accord, and wages policy, are thus facing their greatest challenges. The Accord partners are in an interesting Catch-22 situation: a breakdown of the Accord and wages policy will have electoral consequences for Labor; the present prognostications are that Labor will lose office anyway, a situation which suggests to some union leaders that the costs associated with keeping the Accord alive may not return any long-term dividends.

\section{Conclusion}

This article has reviewed Australian wage determination over the period of the Labor Government. The Accord has been the major instrument for reconciling the vested interests of the industrial wing of the labour movement with the more generalized concerns of the political wing.

There has been much debate in the economic literature regarding the efficacy of wages and incomes policies. They have generally been dismissed as little more than circuit breakers which result in a wages explosion and a return to the status quo once the policies have been lifted. The Australian experience does not support such contentions. The Accord has had remarkable longevity and flexibility. In terms of its basic philosophy of stimulating employment while dampening inflation through wage moderation it has been remarkably successful.

The economic problems confronting Australia, and thus the pressures on the Accord and wages policies, have to do with those aspects of economic management which do not form a coherent part of the Accord which, in essence, is predicated upon economic sovereignty. The increasing internationalization of the Australian economy makes more difficult controls over the prices component of an incomes and prices Accord. In time, this must put increasing pressures on the incomes component.

To date, the Accord has proved a flexible and pragmatic instrument. Whether such flexibility and pragmatism will be sufficient to override the political cycle remains to be seen. Much will depend upon international trade and commerce and, in particular, commodity prices. An improvement in Australia's terms of trade will alleviate the major concern of economic management. Prolonged international recession will inevitably consign Labor to opposition, and the Accord to the history books.

Whatever the future holds, the Accord has been an important instrument for changing wage determination and awards in a socially acceptable and peaceful way. Economic pressures may have achieved similar results. They could have been expected to do so at greater social cost than under the Accord and by the reinforcing of antagonistic labourmanagement relations. 


\section{References}

Australian Conciliation and Arbitration Commission (1983) National Wage Case, reason for decision: September. Canberra (Print F2900).

Australian Conciliation and Arbitration Commission (1984) National Wage Case, reason for decision: April. Canberra (Print F5000).

Australian Conciliation and Arbitration Commission (1985a) National Wage Case, reason for decision: April. Canberra (Print F8100).

Australian Conciliation and Arbitration Commission (1985b) National Wage Case, reason for decision: November. Canberra (Print G0700).

Australian Conciliation and Arbitration Commission (1986a) National Wage Case, reason for decision: June. Canberra (Print G3600).

Australian Conciliation and Arbitration Commission (1986b) National Wage Case, reason for decision: December. Canberra (Print G6400).

Australian Conciliation and Arbitration Commission (1987) National Wage Case, reason for decision: March. Canberra (Print G6800).

Australian Conciliation and Arbitration Commission (1988) National Wage Case, reason for decision: August. Canberra (Print H4000).

Australian Council of Trade Unions (1983) The agreement between the ACTU and the ALP. Melbourne.

Australian Council of Trade Unions (1990) Agreement between the Federal Government and the ACTU. Melbourne.

Australian Industrial Relations Commission (1989a) National Wage Review, reason for decision: February. Canberra (Print H8200).

Australian Industrial Relations Commission (1989b) National Wage Case, reason for decision: August. Canberra (Print H9100).

Department of Industrial Relations (1990) Report on the operation of the restructuring and efficiency principle. Canberra, AGPS.

Moore, Sir John (1983) Report of National Wage Conference. Melbourne, Australian Conciliation and Arbitration Commission.

Moore, Sir John (1984) National Wage Case - Statement by the President, August. Melbourne, Australian Conciliation and Arbitration Commission.

National Economic Summit Communique (1983). Canberra, AGPS.

Plowman, D.H. (1984) Full circle: Australian wage determination 1982-1984. New Zealand journal of industrial relations $9(2): 95-112$.

Plowman, D.H. (1990), Award restructuring: possibilities and portents. The economic and labour relations review 1(1):15-40. 